Article

\title{
Anthropogenic Effects on Hydrogeochemical Characterization of the Shallow Groundwater in an Arid Irrigated Plain in Northwestern China
}

\author{
Luchen Wang ${ }^{1}$, Yi Mei ${ }^{1}$, Kun Yu ${ }^{1, *}$, , Ying Li ${ }^{1,2,3}$, Xuchen Meng ${ }^{3}$ and Fusheng $\mathrm{Hu}^{1}$ \\ 1 School of Water Resources and Environment, China University of Geosciences (Beijing), Beijing 100083, \\ China; wangluchen@cugb.edu.cn (L.W.); meiyi@cugb.edu.cn (Y.M.); ytly1989@163.com (Y.L.); \\ 1991010439@cugb.edu.cn (F.H.) \\ 2 Geological Bureau of Ningxia Hui Autonomous Region, Yinchuan 750021, China \\ 3 Institute of Hydrogeology and Environmental Geology of Ningxia, Yinchuan 750011, China; \\ wyn1989@live.cn \\ * Correspondence: yukun@cugb.edu.cn
}

Received: 28 August 2019; Accepted: 23 October 2019; Published: 26 October 2019

\begin{abstract}
Many irrigated plains in arid and semi-arid regions have groundwater quality issues due to both intensive human activity and natural processes. Comprehensive studies are urgently needed to explore hydrogeochemical evolutions, investigate possible pollution sources, and understand the controls on groundwater compositions in such regions. Here, we combine geostatistical techniques and hydrogeochemical assessments to characterize groundwater quality over time in the Yinchuan Plain (a typical irrigated plain in China), using 12 physicochemical variables derived from sampling in 600 and 602 wells in 2004 and 2014, respectively. Our results show that groundwater-rock interactions and evaporation are the key natural factors controlling groundwater compositions. Hydrogeochemical water types in both 2004 and 2014 were $\mathrm{Ca}-\mathrm{HCO}_{3}, \mathrm{Na}-\mathrm{Cl}$, and mixed $\mathrm{Ca} \cdot \mathrm{Mg}-\mathrm{Cl}$. Along with the hydrogeochemical compositions, we used ionic ratios and the saturation index to delineate mineral solution reactions and weathering processes. Dissolution of gypsum, halite, fluorite, and mirabilite, along with silicate weathering and cation exchange, were identified in the study area. Our results indicated rising ion concentrations in groundwater, which could be the result of anthropogenic influences. Increasing total hardness and nitrates over the study period were most likely caused by agricultural activity and the discharge of waste water from human residential areas.
\end{abstract}

Keywords: hydrogeochemical evolution; groundwater quality; irrigation; land use; correspondence analysis; pollution sources

\section{Introduction}

Although groundwater is a crucial source of fresh water for human survival in arid and semi-arid regions, rapid population growth and economic development have degraded regional groundwater resources $[1,2]$. Problems include depletion by intensive agricultural activity, quality degradation by increased fertilizers use, and pollution from urbanization and inappropriate sewage treatment [3-6]. Industrial effects include over-exploitation in mining areas, excess concentrations of heavy metals and toxic ions in discharged mine water, and contamination near industrial areas [7,8]. In China, major groundwater issues include health risks related to nitrate pollution and dispersion $[9,10]$, increasing water scarcity due to declining river discharge in northern basins, over-exploitation, and other environmental problems [11-13]. China's food production depends highly on irrigation. Climate change has further aggravated water scarcity in several river basins in northern China, resulting in a reduction of irrigation in farmlands areas and lower food production [14,15]. 
The Yinchuan Plain in northwestern China is a semi-arid region with a centuries-old history of irrigated agriculture development. It plays a key role in the development of the Yellow River Economic Belt, which has drastically increased human activity in this region over the past decade. Problems typical of agricultural and industrial development have followed, including water scarcity, degradation of water quality, excessive groundwater exploitation, and inadequate sewage treatment [16-18]. Additionally, water table depression cones have been formed by groundwater over-exploitation; large quantities of infiltrated irrigation water flow into these cones, easily contaminating the groundwater via such irrigation return flow [19]. Previous studies have assessed possible hydrogeochemical mechanisms for pollutant sourcing and distribution in the region's groundwater, using annual or seasonal (dry or rainy) data [9,20], but more detailed spatio-temporal hydrogeochemical analyses over a $10-y r$ period have yet to be performed.

Additionally, no efforts have been made to understand the causes of pollutants and to discriminate the natural and anthropogenic influences on groundwater quality during long-term irrigation and urban change. Herein, we apply a comprehensive methodology using multivariate statistics, geostatistical analysis, and hydrogeochemical analysis to explore the spatio-temporal evolution of the relationship between irrigation, urban change and natural/ anthropogenic pollution sources over a 10-yr period. We used Piper plots, Gibbs plots, and ionic ratios to identify typical pollutants; to understand their source and spatio-temporal distribution characteristics, we use correspondence analysis with various graphical methods, saturation indices, and geographic information systems.

\section{Materials and Methods}

\subsection{Study Area}

The Yinchuan Plain is located in the northern Ningxia Hui Autonomous Region of China (Figure 1). This region is an important upper catchment of the Yellow River basin, with a total area of $\sim 7790 \mathrm{~km}^{2}$ bounded by the Helan Mountains to the west and the Ordos Basin to the east, and an altitude range of 1100-1200 m above sea level. The plain is underlain by Quaternary sediments and can be divided into a leaning pluvial plain, an alluvial-pluvial plain, and an alluvial-lacustrine plain from the piedmont zone to the Yellow River [21]. The main subsurface reservoir of the catchment is a porous aquifer subsystem in loose Quaternary sediments. From west to east, the lithology of the aquifer changes from gravel to sand and sandy gravel, with thicknesses ranging from 300-500 m near the Helan Mountains and greater than $1400 \mathrm{~m}$ in the center (near Yinchuan) to only tens of meters near the Yellow River [22].

The study area has a temperate continental arid climate, characterized by low annual precipitation, high evapotranspiration, and large seasonal precipitation and temperature variations. The annual average rainfall is $171 \mathrm{~mm}$, while the annual mean evaporation is $1689 \mathrm{~mm}$. Evapotranspiration accounts for more than $45 \%$ of the total outflow from the catchment, while human exploitation accounts for more than $27 \%$. Water redirected from the Yellow River has been the key resource for irrigated grain production in this area for the past $2000 \mathrm{yrs}$. However, large amounts of water are now being lost because of leakage from irrigation channels, which accounts for an estimated $80 \%$ of total groundwater recharge in the area.

The middle of the Yinchuan Plain is densely populated and highly industrialized with a highly developed agriculture sector, along with some independent industrial and mining land. The principal crops are wheat, rice, and corn (maize). The main land use type (Figure S1) is agricultural (paddy fields, irrigated land, vegetable fields, and orchards), mostly distributed along the Yellow River's bank. Agricultural lands account for more than $55 \%$ of the total area, whereas urbanized areas account for approximately $14 \%$, and unused land more than $30 \%$. 


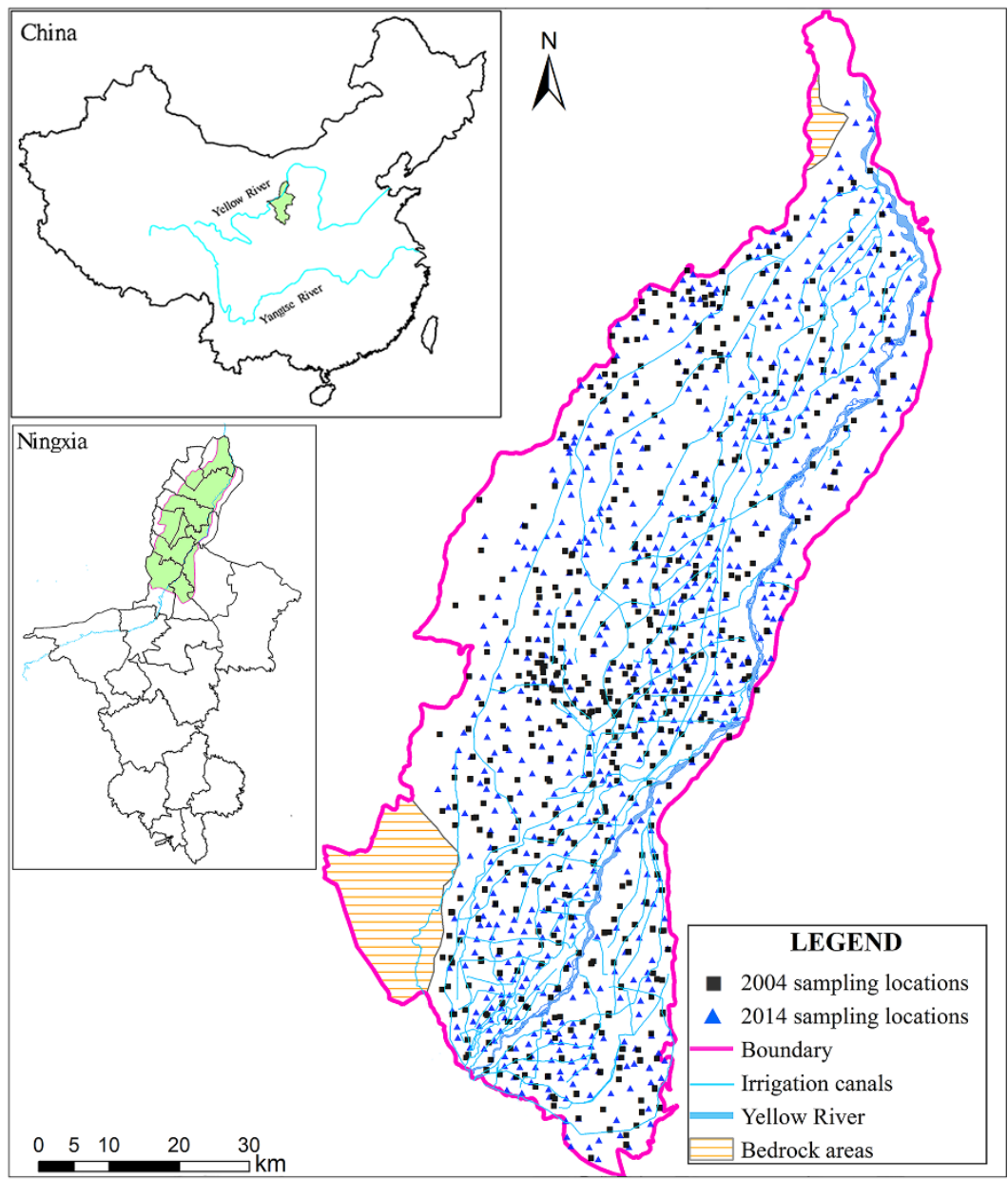

Figure 1. Map of the study area (Yinchuan plain) showing groundwater sampling locations in Ningxia, China.

\subsection{Data Collection and Analytical Methods}

We collected groundwater samples from active phreatic wells (600 in 2004 and 602 in 2014) as part of the "Hydrogeological and Environmental Geological Survey of Ningxia Yellow River Economic Belt" and "Groundwater Exploitation and Utilization \& Ecological Environmental Protection Survey of Ningxia Yellow River Ecological and Economic Belt" project (Figure 1). We chose representative sampling sites based on the overall state of groundwater quality and pollution based on previous studies [17,21,22]. All of the water samples from 2004 and 2014 were collected from the pre-cleaned wells, and were kept in $1 \mathrm{~L}$ colored glass bottles to remove stagnant water from the wells. After collection, water samples were stored in ice-containing insulated containers, shifted to the laboratory, and preserved at $4{ }^{\circ} \mathrm{C}$ within 7 days for further analysis. During the sampling, we measured air temperature along with water temperature, $\mathrm{pH}$, electrical conductivity, and redox potential. Organic and inorganic parameters were tested in the laboratory, of which we used $\mathrm{pH}$, total dissolved solids (TDS), total hardness (TH), $\mathrm{K}^{+}, \mathrm{Ca}^{2+}, \mathrm{Na}^{+}, \mathrm{Mg}^{2+}, \mathrm{HCO}_{3}^{-}, \mathrm{SO}_{4}^{2-}, \mathrm{Cl}^{-}, \mathrm{F}^{-}$, and $\mathrm{NO}_{3}^{-}$(all units in $\mathrm{mg} / \mathrm{L}$ except $\mathrm{pH}$ ). The analytical procedures, quality assurance, quality control, and precision adopted in this study were based on the methods described by Chinese detection standards [23]. The content of $\mathrm{Ca}^{2+}, \mathrm{Mg}^{2+}$, and $\mathrm{TH}$ were determined by ethylene diamine tetraacetic acid (EDTA) titration. The determination of potassium, sodium, sulfate, chloride, nitrate, and fluorine ions were described by ion chromatography. The $\mathrm{HCO}_{3}^{-}$in groundwater was analyzed by titration. These analyses were conducted in the laboratory of Geological Bureau of Ningxia Hui Autonomous Region. 
Piper-plots are normally used to reflect the hydrogeochemical type and relative content of major anions and cations in different samples, and to estimate the hydrochemistry of aquifers $[2,24,25]$. Normal water types are shown in a central diamond, whereas the relative concentrations of anions and cations are shown in triangles on either side.

Gibbs plots are used to illustrate natural mechanisms controlling groundwater chemistry such as atmospheric precipitation, water-rock interactions, and evaporation-concentration processes [26,27]. TDS values are plotted against the weight ratios of $\mathrm{Na}^{+} /\left(\mathrm{Na}^{+}+\mathrm{Ca}^{2+}\right)$ and $\mathrm{Cl}^{-} /\left(\mathrm{Cl}^{-}+\mathrm{HCO}_{3}^{-}\right)$. Low-salinity samples fall on the lower right of the plot (the precipitation zone), where the $\mathrm{Na}^{+} /\left(\mathrm{Na}^{+}\right.$ $\left.+\mathrm{Ca}^{2+}\right)$ and $\mathrm{Cl}^{-} /\left(\mathrm{Cl}^{-}+\mathrm{HCO}_{3}^{-}\right)$ratios are nearly equal to 1 , showing that the water chemistry is controlled by the amount of dissolved salts furnished by precipitation. Moderate-salinity samples with lower $\mathrm{Na}^{+} /\left(\mathrm{Na}^{+}+\mathrm{Ca}^{2+}\right)$ and $\mathrm{Cl}^{-} /\left(\mathrm{Cl}^{-}+\mathrm{HCO}_{3}^{-}\right)$ratios $(<0.5)$ are distributed in the middle-left of the plot (the rock weathering zone), suggesting that this is the dominate controlling factor of the water chemistry. High-salinity samples with high $\mathrm{Na}^{+} /\left(\mathrm{Na}^{+}+\mathrm{Ca}^{2+}\right)$ or $\mathrm{Cl}^{-} /\left(\mathrm{Cl}^{-}+\mathrm{HCO}_{3}^{-}\right)$ratios (near 1) are located in the top right corner of the plot (the evaporation-concentration zone), indicating that this is the dominant controlling factor.

As porous media have a significant control effect on the hydrochemistry of nearby groundwater, mineral equilibrium calculations can predict the thermodynamic control on the composition of groundwater that has equilibrated with various minerals. For example, ionic ratios are used to determine the origin of, and hydro-geochemical processes affecting groundwater chemical composition [28,29]. We used the saturation index (SI) to predict the reactive mineralogy of the subsurface from groundwater samples, as this method does not require the collection of solid phase samples and or mineralogy analysis [30,31]. For groundwater samples, SI can be calculated as:

$$
\mathrm{SI}=\lg (\mathrm{IAP} / \mathrm{K}),
$$

where IAP is the Ion Activity product and $\mathrm{K}$ is the equilibrium constant [32]. An SI value of 0 indicates an equilibrium between the mineral and the solution, whereas $\mathrm{SI}>0$ indicates that the groundwater is supersaturated and that these minerals will be precipitated from solution, and SI $<0$ indicates that the groundwater is undersaturated and minerals may stay dissolved [1].

We used Pearson's correlation matrices to determine correlations between major chemicals, as well as to analyze hydrogeochemical characteristics, sources, and tendencies. The parametric data was calculated by this method. This technique provides an effective way of exploring the relationship between multiple chemicals and is helpful for understanding the sources of chemical components. A correlation coefficient ( $\mathrm{r}$ ) higher than 0.7 implies a strong correlation between two parameters, whereas $0.5<\mathrm{r}<0.7$ represents a moderate correlation at a significance level $p<0.05$.

Correspondence analysis is a simultaneous linear regression scheme with dual scaling that allows the interpretation of both sample sites and variables in the same factor space [33]. The handling and representation are conducted by calculating a similarity matrix of the data which then undergoes a statistical transformation involving its diagonalization and the extraction of the eigenvectors and eigenvalues [34]. Correspondence analysis plots include two factor axes (Factor 1 and Factor 2) and the location of both the sample points and the hydrogeochemical variables. The Factor 1 (F1) axis is related to the largest eigenvalue and can explain the greatest amount of total variance. The location of both the sample points and the variables can help interpret their relationship: (1) the closer the variables, the greater the correlation between them, (2) the closeness of variable(s) and sample(s) can indicate that the same underlying processes are determining such proximity in the plotting positions [33]. We used this method to identify controls on groundwater pollution, especially with regard to large hydrogeochemical datasets.

To determine the spatio-temporal variation of groundwater contamination over the 10-yr period from 2004-2014, we also used spatial distributions analysis of major groundwater pollutants, including $\mathrm{TH}$, TDS, chloride, and nitrate, which involved the mapping of chemical parameters using geostatistical methods and box plots. The spatial distributions of these four parameters were displayed using 
the ordinary kriging approach, an optimal spatial interpolation method in which the values of the random field at an unsampled location are estimated on the basis of the linear combination of the given values of the measured locations [35]. To give a more accurate estimate of model prediction performance, cross-validation tests for the kriging approaches of four groundwater quality items were performed $[35,36]$.

\section{Results and Discussion}

\subsection{Chemical Characteristics and Groundwater Quality}

We compared the variations in groundwater quality parameter concentrations from 2004 and 2014 with permissible limits for drinking water set by the World Health Organization (WHO) [37] and Chinese regulations [38] (Table 1). The pH ranges of 6.7-8.7 in 2004 and 6.9-8.9 in 2014 show that the study area's groundwater was neutral to weakly alkaline. The abundance of major cations followed in the order $\mathrm{Na}^{+}>\mathrm{Ca}^{2+}>\mathrm{Mg}^{2+}>\mathrm{K}^{+}$in both 2004 and 2014, whereas major anions followed in the order $\mathrm{HCO}_{3}^{-}>\mathrm{SO}_{4}^{2-}>\mathrm{Cl}^{-}$. The average concentrations of TDS, $\mathrm{TH}, \mathrm{Na}^{+}, \mathrm{Ca}^{2+}, \mathrm{Mg}^{2+}, \mathrm{Cl}^{-}, \mathrm{SO}_{4}^{2-}$, $\mathrm{HCO}_{3}^{-}, \mathrm{F}^{-}$, and $\mathrm{NO}_{3}^{-}$all increased from 2004 to 2014, unlike $\mathrm{K}^{+}$. Most parameters' mean values in 2004 were within the permissible limits set by the WHO and Chinese standards, except TDS, $\mathrm{Mg}^{2+}$, $\mathrm{SO}_{4}^{2-}$, and $\mathrm{HCO}_{3}^{-}$. Only half of the parameters' mean values met the standards in 2014; TDS, TH, $\mathrm{Na}^{+}$, $\mathrm{Mg}^{2+}, \mathrm{SO}_{4}^{2-}$, and $\mathrm{HCO}_{3}^{-}$did not. Hence, a substantial portion of the groundwater in the study area was unacceptable for drinking, especially in 2014.

Table 1. Basic statistics of groundwater quality parameters in 2004 and 2014.

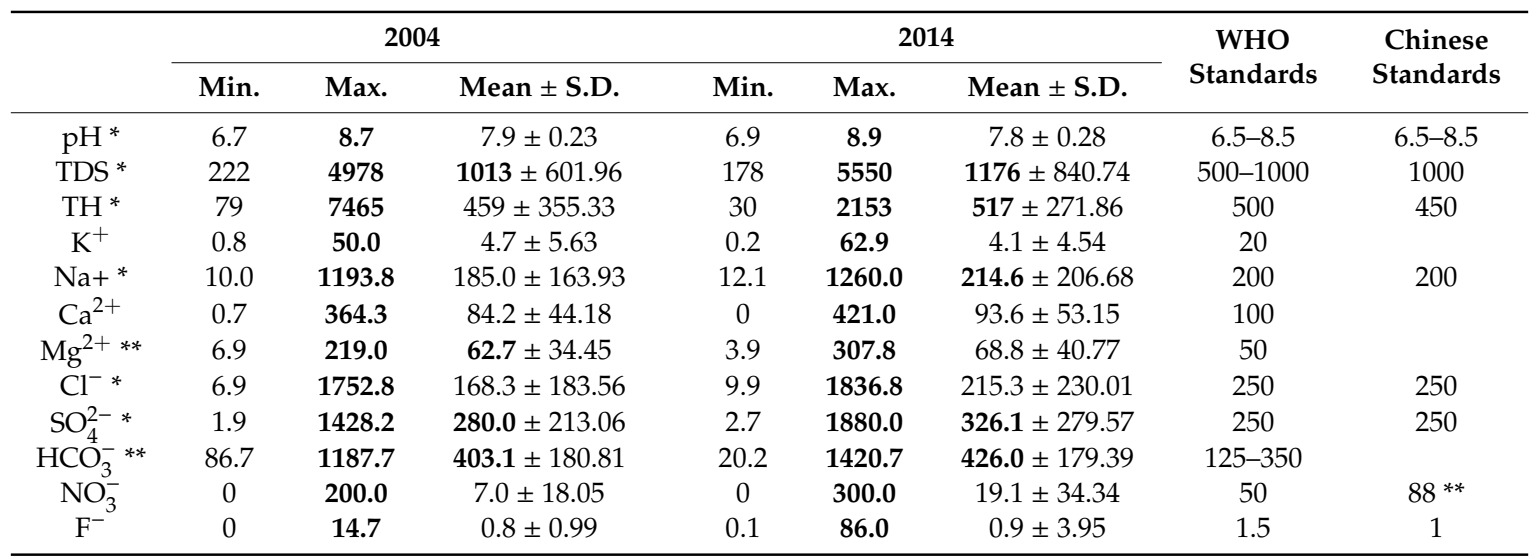

Note: TDS, Total dissolved solids; TH, Total hardness; $\mathrm{K}^{+}$, Potassium; $\mathrm{Na}^{+}$, Sodium; $\mathrm{Ca}^{2+}$, Calcium; $\mathrm{Mg}^{2+}$, Manganese; $\mathrm{Cl}^{-}$, Chloride; $\mathrm{SO}_{4}^{2-}$, Sulfate; $\mathrm{HCO}_{3}^{-}$, Bicarbonates; $\mathrm{NO}_{3}^{-}$, Nitrate; $\mathrm{F}^{-}$, fluoride. Max values and mean values above permissible WHO limits are indicated in bold. * Not of health concern at levels found in drinking-water [37]. ** $\mathrm{NO}_{3}^{-}-\mathrm{N} \leq 20$ in Chinese standards [38].

Piper plots for $\mathrm{Ca}-\mathrm{HCO}_{3}, \mathrm{Na}-\mathrm{Cl}$, and mixed $\mathrm{Ca} \cdot \mathrm{Mg}-\mathrm{Cl}$ in 2004 and 2014 showed that few samples fell in the $\mathrm{Ca}-\mathrm{Cl}$ and $\mathrm{Ca} \cdot \mathrm{Na}-\mathrm{HCO}_{3}$ zones (Figure 2). No obvious changes in groundwater type occurred between 2004 and 2014. Overall, the concentrations of alkali earth metals and strong acid ions were relatively high in the study area during the research period.

\subsection{Correlation of Groundwater Parameters}

The Pearson's correlation matrices showed that $\mathrm{Na}^{+}, \mathrm{SO}_{4}^{2-}$, and $\mathrm{Cl}^{-}$concentrations had strongly positive correlations in both 2004 and 2014 (Table 2). This generally high correlation between sodium and chloride has been widely used in arid and semi-arid regions to identify salinity mechanisms such as the dissolution of halite deposits and evaporation [39,40]. The coexistence of $\mathrm{Na}^{+}$and $\mathrm{SO}_{4}^{2-}$ may be attributed to dissolution of mirabilite or the use of gypsum and sodium sulfate fertilizer. A good correlation between $\mathrm{SO}_{4}^{2-}$ and $\mathrm{Cl}^{-}$suggests similar origins related to the dissolution of sulfate-rich 
minerals, secondary evaporate minerals, the contribution of relict sulfide, and agricultural activity [41] as well as sewage discharge. $\mathrm{Na}^{+}, \mathrm{Mg}^{2+}, \mathrm{Cl}^{-}$, and $\mathrm{SO}_{4}^{2-}$ were more strongly correlated with TDS in 2004 than in 2014, possibly because of these elements' contribution to groundwater mineralization and salinity. TH had a strong correlation with $\mathrm{Ca}^{2+}, \mathrm{Mg}^{2+}$, and $\mathrm{SO}_{4}^{2-}$ in 2014 (Table 2) indicating the permanent nature of water hardness [42]. Strongly correlated $\mathrm{Mg}^{2+}$ and $\mathrm{SO}_{4}^{2-}$ indicated the possibility of magnesium sulfate fertilizer application in this area.
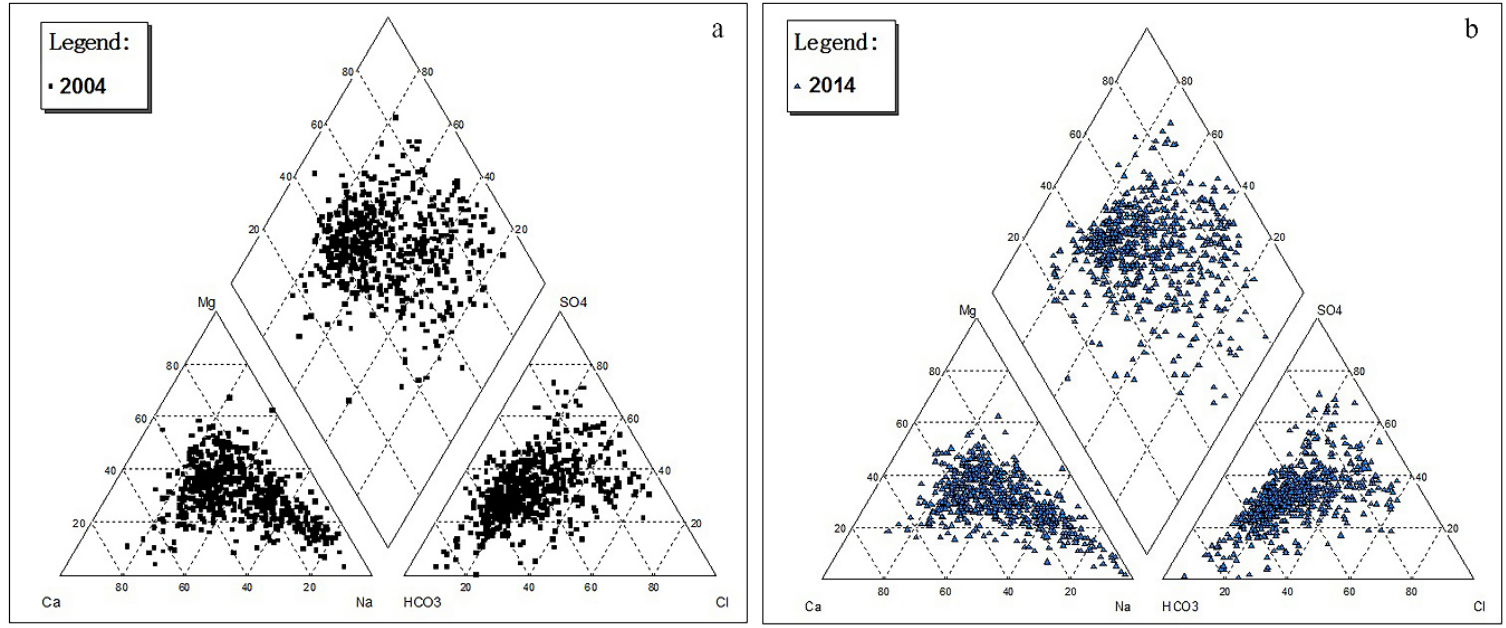

Figure 2. Piper plots illustrating the groundwater chemistry/water type for samples in (a) 2004 and (b) 2014 .

Table 2. Pearson correlation coefficient matrix of 12 physico-chemical variables of groundwater samples for 2004 and 2014.

\begin{tabular}{|c|c|c|c|c|c|c|c|c|c|c|c|c|}
\hline & $\mathrm{pH}$ & TDS & TH & $\mathrm{K}^{+}$ & $\mathrm{Na}^{+}$ & $\mathrm{Ca}^{2+}$ & $\mathrm{Mg}^{2+}$ & $\mathrm{Cl}^{-}$ & $\mathrm{SO}_{4}^{2-}$ & $\mathrm{HCO}_{3}^{-}$ & $\mathrm{NO}_{3}^{-}$ & $\mathbf{F}^{-}$ \\
\hline \multicolumn{13}{|l|}{2004} \\
\hline $\mathrm{pH}$ & 1 & & & & & & & & & & & \\
\hline TDS & $-0.22 * *$ & 1 & & & & & & & & & & \\
\hline $\mathrm{TH}$ & $-0.18^{* *}$ & $0.48^{* *}$ & 1 & & & & & & & & & \\
\hline $\mathrm{K}^{+}$ & $0.14^{* *}$ & $0.28^{* *}$ & $0.11^{* *}$ & 1 & & & & & & & & \\
\hline $\mathrm{Na}^{+}$ & $-0.15^{* *}$ & $0.92 * *$ & $0.30 * *$ & $0.22^{* *}$ & 1 & & & & & & & \\
\hline $\mathrm{Ca}^{2+}$ & $-0.33^{* *}$ & $0.53^{* *}$ & $0.55^{* *}$ & 0.08 * & $0.27^{* *}$ & 1 & & & & & & \\
\hline $\mathrm{Mg}^{2+}$ & $-0.16^{* *}$ & $\overline{0.73}$ ** & $\overline{0.55}^{* *}$ & $0.28^{* *}$ & 0.52 ** & $0.48^{* *}$ & 1 & & & & & \\
\hline $\mathrm{Cl}^{-}$ & $-0.21 * *$ & $0.91^{* *}$ & $\overline{0.40}^{* *}$ & $0.18^{* *}$ & $\overline{0.89}^{* *}$ & $0.47^{* *}$ & 0.59 ** & 1 & & & & \\
\hline $\mathrm{SO}_{4}^{2-}$ & $-0.17^{* *}$ & $0.90^{* *}$ & $0.40^{* *}$ & $0.22^{* *}$ & 0.81 ** & $0.44^{* *}$ & $\overline{0.66}^{* *}$ & $0.74^{* *}$ & 1 & & & \\
\hline $\mathrm{HCO}_{3}^{-}$ & $-0.18^{* *}$ & $0.37^{* *}$ & $0.35^{* *}$ & $0.26^{* *}$ & $0.28^{* *}$ & $0.35^{* *}$ & $\overline{0.54}^{* *}$ & $0.18^{* *}$ & $0.11 * *$ & 1 & & \\
\hline $\mathrm{NO}_{3}^{-3}$ & $-0.13^{* *}$ & 0.12 ** & 0.04 & -0.05 & 0.09 * & $0.12^{* *}$ & 0.02 & $0.08^{*}$ & $0.13 * *$ & $-0.10 *$ & 1 & \\
\hline $\mathrm{F}^{-3}$ & 0.04 & 0.25 ** & -0.03 & $0.30 * *$ & 0.29 ** & $-0.15^{* *}$ & $0.09^{*}$ & $0.19^{* *}$ & $0.25^{* *}$ & 0.04 & $0.12 * *$ & 1 \\
\hline \multicolumn{13}{|l|}{2014} \\
\hline $\mathrm{pH}$ & 1 & & & & & & & & & & & \\
\hline TDS & 0.05 & 1 & & & & & & & & & & \\
\hline $\mathrm{TH}$ & $-0.17^{* *}$ & 0.05 & 1 & & & & & & & & & \\
\hline $\mathrm{K}^{+}$ & $0.09 *$ & 0.10 * & $0.33^{* *}$ & 1 & & & & & & & & \\
\hline $\mathrm{Na}+$ & 0.07 & $0.14^{* *}$ & $0.49^{* *}$ & $0.26^{* *}$ & 1 & & & & & & & \\
\hline $\mathrm{Ca}^{2+}$ & $-0.27^{* *}$ & 0.01 & $0.87^{* *}$ & $0.24^{* *}$ & $0.28^{* *}$ & 1 & & & & & & \\
\hline $\mathrm{Mg}^{2+}$ & -0.06 & 0.08 * & $0.93 * *$ & $0.35^{* *}$ & $0.58^{* *}$ & $0.64^{* *}$ & 1 & & & & & \\
\hline $\mathrm{Cl}^{-}$ & 0.01 & $0.10^{* *}$ & $0.63^{* *}$ & $0.30^{* *}$ & $0.92 * *$ & 0.44 ** & $0.68^{* *}$ & 1 & & & & \\
\hline $\mathrm{SO}_{4}^{2-}$ & 0 & $0.13^{* *}$ & $\overline{0.77}^{* *}$ & $0.28^{* *}$ & $0.82 * *$ & 0.61 ** & $\overline{0.77}^{* *}$ & $0.80^{* *}$ & 1 & & & \\
\hline $\mathrm{HCO}_{3}^{-}$ & $-0.15^{* *}$ & 0.03 & $0.49^{* *}$ & $0.25^{* *}$ & $0.39^{* *}$ & $\overline{0.36}{ }^{* *}$ & $\underline{0.51}^{* *}$ & $0.30 * *$ & $0.27^{* *}$ & 1 & & \\
\hline $\mathrm{NO}_{3}^{-}$ & $0.13^{* *}$ & 0.07 & $0.19^{* *}$ & $0.19^{* *}$ & 0.01 & $0.18^{* *}$ & 0.17 ** & 0.01 & 0.12 * & -0.09 & 1 & \\
\hline $\mathrm{F}^{-3}$ & 0.06 & $0.13^{* *}$ & -0.07 & -0.01 & 0.04 & $-0.09 *$ & -0.04 & -0.01 & 0.01 & -0.04 & 0.08 & 1 \\
\hline
\end{tabular}

Note: TDS, Total dissolved solids; TH, Total hardness; $\mathrm{K}^{+}$, Potassium; $\mathrm{Na}^{+}$, Sodium; $\mathrm{Ca}^{2+}, \mathrm{Calcium}^{2} \mathrm{Mg}^{2+}$, Manganese; $\mathrm{Cl}^{-}$, Chloride; $\mathrm{SO}_{4}^{2-}$, Sulfate; $\mathrm{HCO}_{3}^{-}$, Bicarbonates; $\mathrm{NO}_{3}^{-}$, Nitrate; $\mathrm{F}^{-}$, fluoride. $\mathrm{r}>0.7$ are written in bold; $0.5<\mathrm{r}<0.7$ are underlined. ${ }^{* *}$ Correlation significant at $p<0.01$ level. ${ }^{*}$ Correlation significant at $p<0.05$ level. 


\subsection{Natural Mechanisms Controlling Groundwater Chemistry}

\subsubsection{Gibbs Plots}

All samples were clustered in the upper-middle part of the Gibbs plots (Figure 3), suggesting that evaporation-crystallization was the primary mechanism controlling groundwater chemistry in both years, followed by rock weathering as a secondary process. Evaporation greatly increases the concentrations of ions formed by chemical weathering [43,44]; this is a key process in the semi-arid study area: it can increase salinity by increasing $\mathrm{Na}^{+}$and $\mathrm{Cl}^{-}$content, resulting in increased TDS [40]. The concentrations of $\mathrm{Cl}^{-}$and $\mathrm{HCO}_{3}^{-}$were mostly affected by rock weathering, whereas the evaporation-crystallization process was the major factor leading to higher contents of $\mathrm{Na}^{+}$and $\mathrm{Cl}^{-}$ions (Figure 3a,b). The distribution of samples in 2014 (Figure 3c,d) was wider than that in 2004 (Figure $3 \mathrm{a}, \mathrm{b}$ ), and more samples were located beyond the scope of the three dominant processes, suggesting that anthropogenic activity had a stronger influence on groundwater composition in 2014 than in 2004.
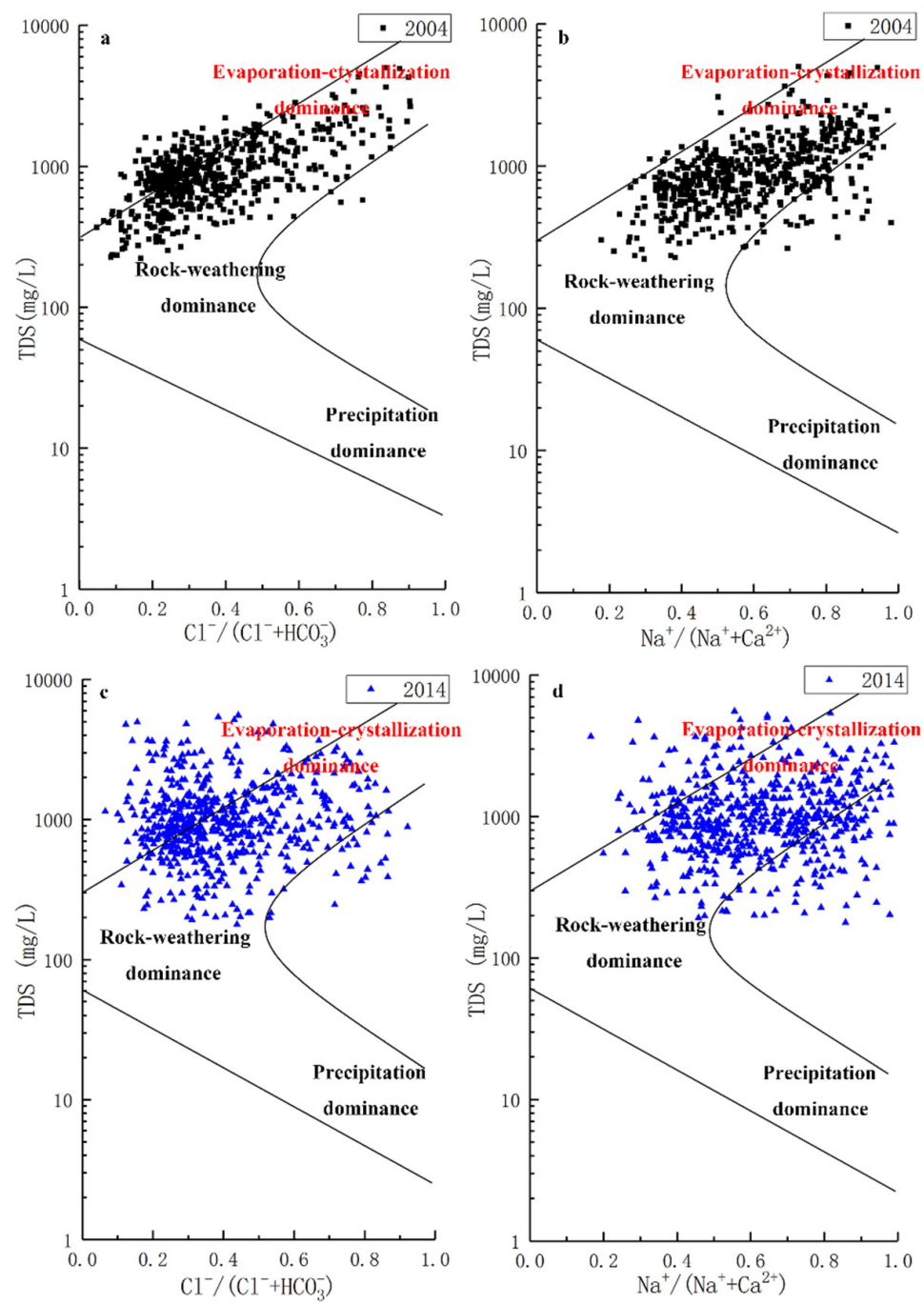

Figure 3. Gibbs plots: diagrammatic representation of processes controlling the chemistry of the study area groundwater, indicating rock-weathering interaction and evaporation-crystallization as the major process regulating the chemistry of the groundwater in the study area. Variation of $\mathrm{Cl}^{-} /\left(\mathrm{Cl}^{-}+\mathrm{HCO}_{3}^{-}\right)$ as a function of the total dissolved solids (TDS) of the study area groundwater in (a) 2004 and (c) 2014; Variation of $\mathrm{Na}^{+} /\left(\mathrm{Na}^{+}+\mathrm{Ca}^{2+}\right)$ as a function of the TDS of the study area groundwater in (b) 2004 and (d) 2014 . 


\subsubsection{Saturation Index}

The SI values of all minerals in 2004 and 2014 showed that the separation between the sediment and dissolution phases of minerals was similar in 2004 and 2014 (Figure 4). The SI values of calcite and dolomite in groundwater samples were almost all greater than 0 , whereas those of gypsum, halite, and fluorite were less 0 . Thus, carbonate minerals (dolomite and calcite) in the study area's aquifers were in a supersaturated condition, whereas gypsum, halite, and fluorite were undersaturated.
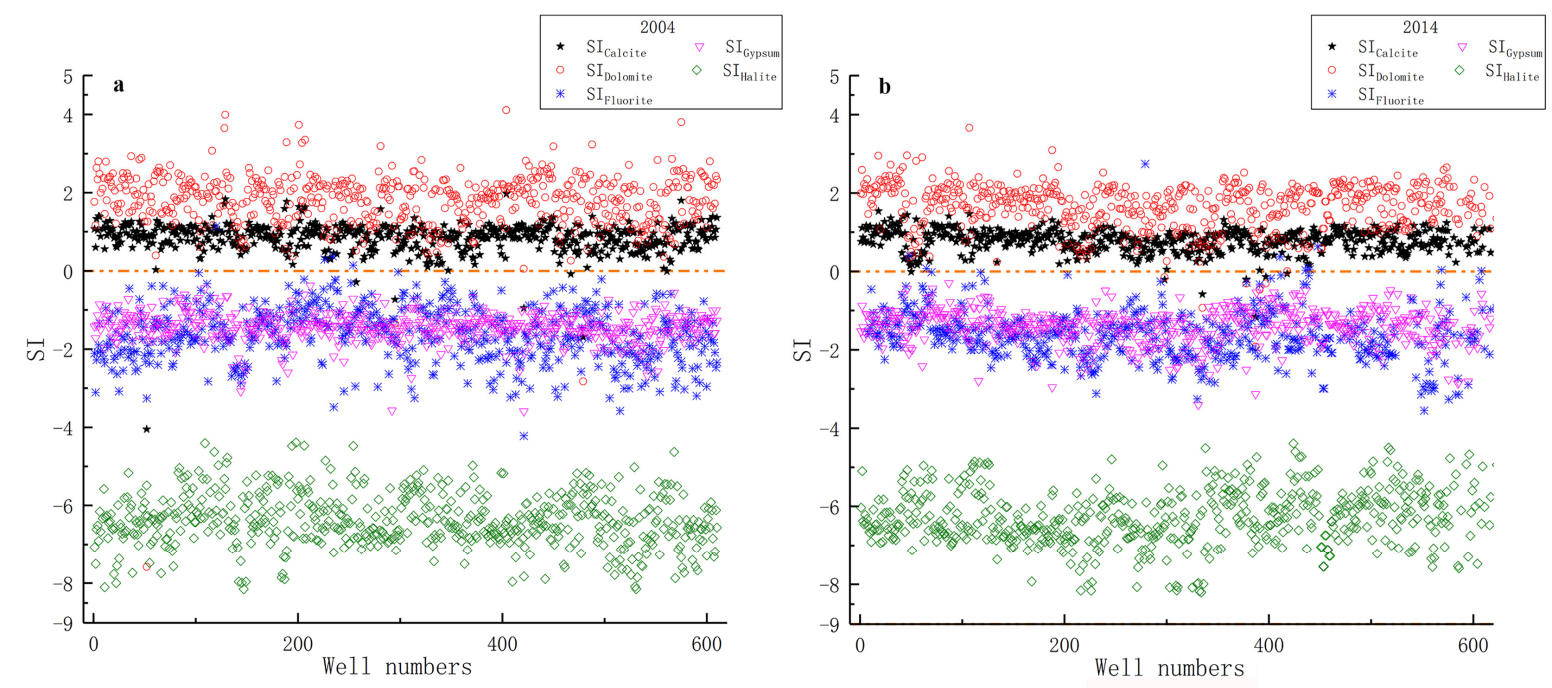

Figure 4. Saturation indices (SIs) for samples in (a) 2004 and (b) 2014.

\subsubsection{Ionic Ratios}

The scatter plot of $\mathrm{Na}^{+}$versus $\mathrm{SO}_{4}^{2-}$ (Figure 5a) shows that $90 \%$ of samples in 2004 and 2014 fell close to the 1:1 line, indicating that mirabilite dissolution and gypsum fertilizer could be the source of $\mathrm{Na}^{+}$and $\mathrm{SO}_{4}^{2-}$. Gypsum (calcium sulfate) fertilizer can be used as a soil amendment in salty alkali soil in arid and semi-arid regions. The reaction of gypsum $\left(\mathrm{CaSO}_{4}\right)$ fertilizer and $\mathrm{Na}_{2} \mathrm{CO}_{3}\left(\right.$ and $\left.\mathrm{NaHCO}_{3}\right)$ in soil solution produces soluble sodium sulfate $\left(\mathrm{Na}_{2} \mathrm{SO}_{4}\right)$, such that gypsum can be combined with freshwater irrigation to improve salinized soil. Samples fell far above the 1:1 line because of the higher sodium content originating from other sources. The scatter plot for $\mathrm{Ca}^{2+}+\mathrm{Mg}^{2+}$ versus $\mathrm{SO}_{4}^{2-}+$ $\mathrm{HCO}_{3}^{-}$(Figure 5b) shows that silicate weathering was more prevalent than carbonate weathering in the study area.

The former represents the reaction of feldspar minerals with carbonate acid in the water, in which bicarbonate is a dominant anion and various other cations are present in groundwater as shown in equation below:

$(\mathrm{Na}, \mathrm{Mg}, \mathrm{Ca}, \mathrm{K})$ silicate $+\mathrm{H}_{2} \mathrm{CO}_{3} \rightarrow \mathrm{H}_{4} \mathrm{Si}_{4}+\mathrm{HCO}_{3}^{-}+\mathrm{Na}^{+}+\mathrm{K}^{+}+\mathrm{Mg}^{2+}+\mathrm{Ca}^{2+}+$ Clays,

In this reaction, sodium ions and a large number of bicarbonate ions are produced by silicate weathering. The predominance of $\mathrm{Ca}^{2+}+\mathrm{Mg}^{2+}$ over $\mathrm{SO}_{4}^{2-}+\mathrm{HCO}_{3}^{-}$could relate their genesis through carbonate weathering, whereas the greater abundance of $\mathrm{SO}_{4}^{2-}+\mathrm{HCO}_{3}^{-}$compared to that of $\mathrm{Ca}^{2+}+$ $\mathrm{Mg}^{2+}$ may reflect silicate weathering [45-47]. 
a

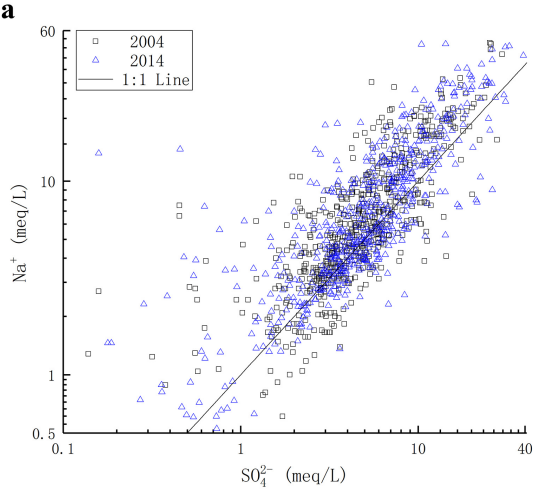

c

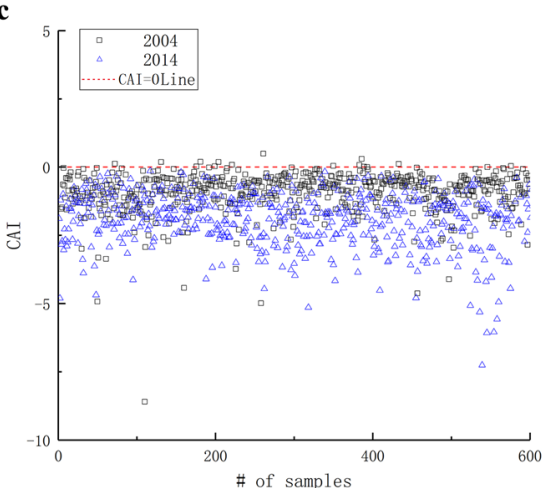

b
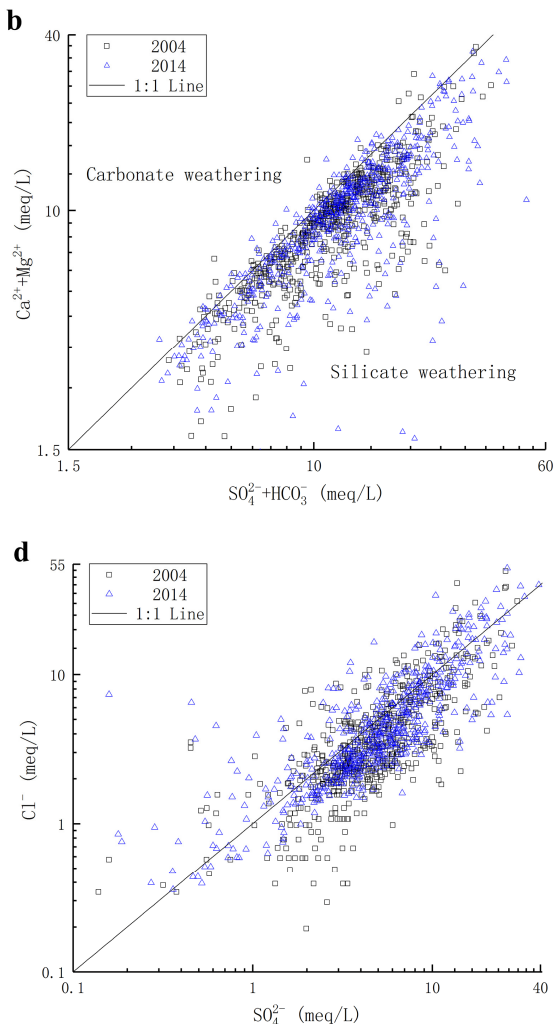

Figure 5. Relationship between hydrochemical composition of groundwater in the study area: (a) $\mathrm{Na}^{+}$ versus $\mathrm{SO}_{4}^{2-}$; (b) $\mathrm{Ca}^{2+}+\mathrm{Mg}^{2+}$ versus $\mathrm{SO}_{4}^{2-}+\mathrm{HCO}_{3}^{-}$; (c) chloro-alkaline indices $(\mathrm{CAI}) ;(\mathbf{d}) \mathrm{Cl}^{-}$versus $\mathrm{SO}_{4}^{2-}$.

The chloro-alkaline index $\left(\mathrm{CAI}=\mathrm{Cl}^{-}-\left(\mathrm{Na}^{+}+\mathrm{K}^{+}\right) / \mathrm{Cl}^{-}\right)$can be used to assess ion exchange in groundwater and the surrounding environment [48], as in the exchange of $\mathrm{Ca}^{2+}$ and $\mathrm{Mg}^{2+}$ in groundwater with $\mathrm{Na}^{+}$and $\mathrm{K}^{+}$studied here $[49,50]$. The results showed negative index values in more than $90 \%$ of samples, indicating $\mathrm{Na}^{+}$and $\mathrm{K}^{+}$enrichment in the study area's groundwater (Figure $5 \mathrm{c}$ ). This was more prominent in 2014 than in 2004.

$\mathrm{SO}_{4}^{2-}$ and $\mathrm{Cl}^{-}$showed a significant $(p<0.05)$ linear correlation (Figure $5 \mathrm{~d}$ ). The values for $\mathrm{SO}_{4}^{2-} / \mathrm{Cl}^{-}$ ranged from $0.12-10.47$ in 2004 and $0.13-4.86$ in 2014. Values $\gg 0.05$ indicate that groundwater quality decrease could be caused by the application of gypsum fertilizers and irrigation return flows [43,51], clearly suggesting that these processes were operative in our study area. These results are consistent with the Pearson's correlation analysis between $\mathrm{Na}^{+}-\mathrm{SO}_{4}^{2-}$ in the previous section.

\subsection{Pollutant Identification}

\subsubsection{Correspondence Analysis}

To ascertain the relationships between pollutants and their potential contributing sources, the groundwater quality indices and sample data which exceeded groundwater standards were subjected to correspondence analysis. As excessive concentrations of $\mathrm{Mg}^{2+}$ and $\mathrm{HCO}_{3}^{-}$pose no threat to human health, no further analyses of these were needed.

The proportion of total variance explained by the extracted factor axes is a function of their eigenvalues. The first two factorial axes are estimated to represent approximately $80 \%$ of the total variance in the 2004 and 2014 data (Table 3). The F1 and F2 axes described approximately $60 \%$ and $18 \%$ of the total variance, respectively. Hence, these two factorial axes played an important role in the groundwater pollution analysis. 
Table 3. Correspondence analysis results from 2004 and 2014 (eigenvalues, contribution rates of principal component, and cumulative contribution rates) for each of six factors.

\begin{tabular}{ccccccc}
\hline No. & \multicolumn{3}{c}{$\mathbf{2 0 0 4}$} & \multicolumn{2}{c}{$\mathbf{2 0 1 4}$} \\
\cline { 2 - 6 } & Eigenvalues & $\begin{array}{c}\text { Contribution } \\
\text { Rates of Principal } \\
\text { Component }\end{array}$ & $\begin{array}{c}\text { Cumulative } \\
\text { Contribution } \\
\text { Rates }\end{array}$ & Eigenvalues & $\begin{array}{c}\text { Contribution } \\
\text { Rates of Principal } \\
\text { Component }\end{array}$ & $\begin{array}{c}\text { Cumulative } \\
\text { Contribution } \\
\text { Rates }\end{array}$ \\
\hline 1 & 0.0745 & $66.15 \%$ & $66.15 \%$ & 0.1512 & $62.73 \%$ & $62.73 \%$ \\
2 & 0.0205 & $18.21 \%$ & $84.37 \%$ & 0.0446 & $18.50 \%$ & $81.23 \%$ \\
3 & 0.0100 & $8.92 \%$ & $93.29 \%$ & 0.0229 & $9.49 \%$ & $90.72 \%$ \\
4 & 0.0037 & $3.25 \%$ & $96.54 \%$ & 0.0117 & $4.87 \%$ & $95.59 \%$ \\
5 & 0.0030 & $2.70 \%$ & $99.24 \%$ & 0.0085 & $3.53 \%$ & $99.12 \%$ \\
6 & 0.0009 & $0.7614 \%$ & $100.00 \%$ & 0.0021 & $0.88 \%$ & $100.00 \%$ \\
\hline
\end{tabular}

In 2004, F1 was associated with waters with high TH concentrations, whereas F2 was related to $\mathrm{Cl}^{-}$ (Figure 6a). The major pollutants were $\mathrm{TH}$ and chloride, whereas $\mathrm{F}^{-}$and $\mathrm{NO}_{3}^{-}$fell close to the ordinate origin with lower factor loadings, indicating that these were not the main pollutants. $\mathrm{SO}_{4}^{2-}$ and $\mathrm{Na}^{+}$ were associated (i.e., they had the same sign along Factor 1) and opposed to TH (TH is the sum of $\mathrm{Ca}^{2+}$ and $\mathrm{Mg}^{2+}$ ). This might be interpreted as a regional process involving the dissolution of gypsum coupled with ion-exchange reactions that soften the groundwater by releasing $\mathrm{Na}^{+}$and trapping $\mathrm{Ca}^{2+}$ and $\mathrm{Mg}^{2+}$ ions. $\mathrm{Na}^{+}$and $\mathrm{Cl}^{-}$were mapped to the second quadrant and TDS and $\mathrm{SO}_{4}^{2-}$ were mapped to the third quadrant; this, which could be explained by the symbiotic relationship existing between these ions. Additionally, the locations of $\mathrm{SO}_{4}^{2-}$ and $\mathrm{Cl}^{-}$were opposed along $\mathrm{F} 2$, which might be related to the mixing of recharge water (or sewage water) with old water [33]. TH was located close to samples collected from rural residential areas, suggesting that hardness content in groundwater might be related to sewage seepage. Overall, the samples collected in 2004 were close to the coordinate axis, indicating that the groundwater was of good quality then.

In 2014, TDS and $\mathrm{SO}_{4}^{2-}$ were associated with samples collected from irrigated farm and paddy field areas in the third quadrant, whereas some samples collected from lake, urban, and paddy field areas were associated with $\mathrm{Na}^{+}$and $\mathrm{Cl}^{-}$(Figure 6b). Thus, we suggest that groundwater hardening and pollution were linked to raw sewage and irrigation return flow. TDS, $\mathrm{TH}$, and $\mathrm{NO}_{3}^{-}$were major contributing factors in 2014. The values of $\mathrm{SO}_{4}^{2-}, \mathrm{Na}^{+}$, and $\mathrm{Cl}^{-}$parameters along $\mathrm{F} 1$ were similar, showing relationships between these ions (Figure $6 \mathrm{~b}$ ). One possible source of enrichment of these could be evaporate dissolution. The inverse distribution of $\mathrm{Cl}^{-}$and $\mathrm{SO}_{4}^{2-}$ along F2 may be related to irrigation return flow.

TDS was located in the position of some samples collected from urban and rural dwelling areas, as well as industrial and mining areas and paddy fields, suggesting that TDS concentrations were related to anthropogenic influences such as sanitary sewage, industrial wastewater discharge, and irrigation return flow. $\mathrm{NO}_{3}^{-}$was located close to sample points located near paddy fields and irrigated land, suggesting that nitrate enrichment may enter the groundwater system through irrigation activity. The spatial distribution of TH and samples from irrigated land and industrial and mining areas implies an agricultural and industrial influence on high groundwater hardness. $\mathrm{Na}^{+}$and $\mathrm{Cl}^{-}$ were associated with most samples from irrigated land and lakes, suggesting a possible origin from water-surface evaporation.

Comparing the plots in Figure $6 \mathrm{a}, \mathrm{b}$ shows that $\mathrm{TH}$ was a primary pollutant during the study period. The distribution of $\mathrm{Cl}^{-}$and $\mathrm{SO}_{4}^{2-}$ was approximately identical in both cases, suggesting the influence of irrigation return flow on groundwater quality. In addition to high-mineralization, nitrogen pollutants were identified as typical pollutants that resulted from evaporation, irrigation return flow, raw sewage and the use of fertilizer. 

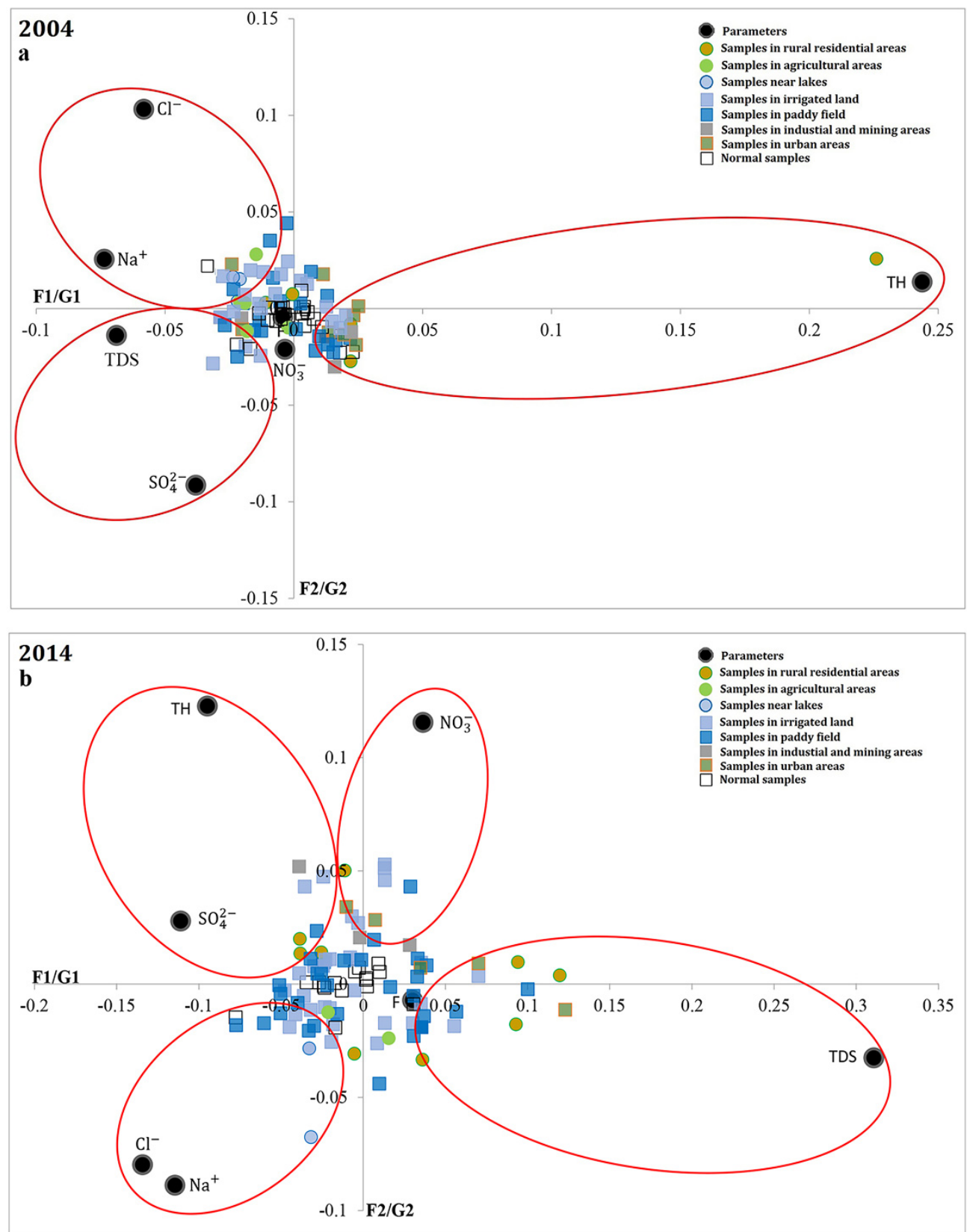

Figure 6. Distribution of variables and samples determined by correspondence analysis for F1 and F2 in (a) 2004 and (b) 2014. The red ellipses are drawn from the close degree of variables and samples.

\subsubsection{Spatial and Temporal Characteristics of Typical Pollutants}

There was obvious spatial variability in the typical pollutants (TH, TDS, $\mathrm{Cl}^{-}, \mathrm{NO}_{3}^{-}$) within the study area (Figure 7). The TDS classification proposed by [52] classifies water salinities into four groups: freshwater (TDS $<1000 \mathrm{mg} / \mathrm{L})$, brackish water $(1000-3000 \mathrm{mg} / \mathrm{L})$, moderately saline water $(3000-10,000 \mathrm{mg} / \mathrm{L})$, and very saline water (TDS $>10,000 \mathrm{mg} / \mathrm{L}$ ). Using this classification, almost half of the samples would be considered brackish, moderately saline, and very saline in 2014 (Figure 7a). The median, upper quartile, and maximum TDS values were obviously higher in 2014 than in 2004, showing the increasing trend of groundwater salinization. 

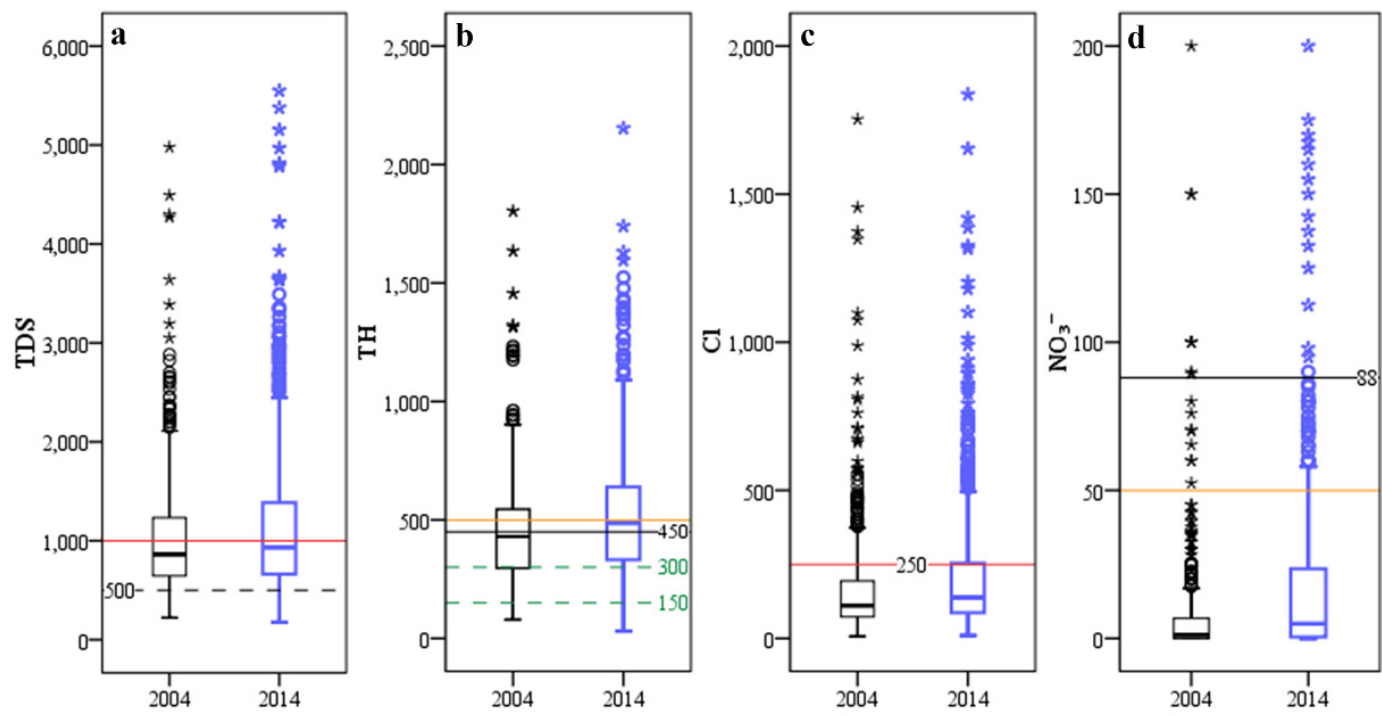

Figure 7. Box plots of samples in 2004 and 2014 for (a) total dissolved solids (TDS), (b) total hardness $(\mathrm{TH}),(\mathrm{c}) \mathrm{Cl}^{-}$, and $(\mathrm{d}) \mathrm{NO}_{3}^{-}-\mathrm{N}$. The red line indicates the permissible limits according to both WHO and Chinese standards, whereas the orange and black lines represent different permissible limits by WHO and Chinese standards, respectively. The dotted green line indicates TH classification.

More than three quarters of samples in 2004 and 2014 were considered very hard water (TH > 300 $\mathrm{mg} / \mathrm{L}$ ), with higher values overall in 2014 than 2004 (Figure 7b). The median value in 2004 was lower than the WHO drinking-water standard $(500 \mathrm{mg} / \mathrm{L})$, whereas the median value in 2014 was between that and the Chinese standard $(450 \mathrm{mg} / \mathrm{L})$. More than $50 \%$ of the groundwater samples in 2014 had TH concentration values beyond permissible limits.

The $\mathrm{Cl}^{-}$concentration differences between samples from 2004 and 2014 were slightly significant (Figure 7c). About $25 \%$ of $\mathrm{Cl}^{-}$in 2014 samples exceeded the drinking water standard $(250 \mathrm{mg} / \mathrm{L})$, more than that in 2004. There was a significant spatial variation in $\mathrm{NO}_{3}^{-}$concentrations between 2004 and 2014 (Figure 7d). The wider range of $\mathrm{NO}_{3}^{-}$distribution in 2014 showed an increased trend in concentration over the study period.

It can be seen that the geographical distribution of different concentration categories is the same as in that of the sampling wells (Figure 8). The concentrations obtained from the kriging approach are in good consistency with the actual monitored concentrations, demonstrating the kriging approach's excellent prediction performance [36].

The spatial distribution of TDS concentrations varied considerably from 2004-2014 (Figure 8a,b). In 2004, most samples had TDS values below the safe limit $(1000 \mathrm{mg} / \mathrm{L})$. Samples in the western part of the plain (the recharge area) had lower TDS values, which then rose along the flow direction from southwest to northeast toward the discharge area along the Yellow River. In 2014, more samples were above the permissible limit than in 2004. Typically, the distribution of TDS in groundwater follows a horizontal zoning controlled by topography, lithology, and subsurface conditions, though this may also be influenced by human activity in some areas [22]. Thus, our results suggest that higher groundwater salinization in some areas may be caused by urban and rural factors such as untreated waste water and irrigation return water. For example, large quantities of irrigation return flow can elevate groundwater levels, increasing evaporation and inducing salinization [20]. Intensive irrigation can also have a significant influence on water-rock interactions [17].

The spatial distributions of TH and $\mathrm{Cl}^{-}$were similar to that of TDS in 2004 (Figure 8c,e), with the same sectors of high concentration and the same gradual increase from southwest to northeast. This pattern reflects an increase in solute load with groundwater residence time [53] in which the discharge area shows the highest level of these parameters (TDS, TH, and $\mathrm{Cl}^{-}$). In 2014, groundwater hardness was higher over a wider area than that in 2004 (Figure 8d), especially in urban regions, 
such as Shizuishan, Yinchuan, Lingwu (Figure $8 \mathrm{c}, \mathrm{d}$ ), suggesting possible contributions from domestic sewage leakage.
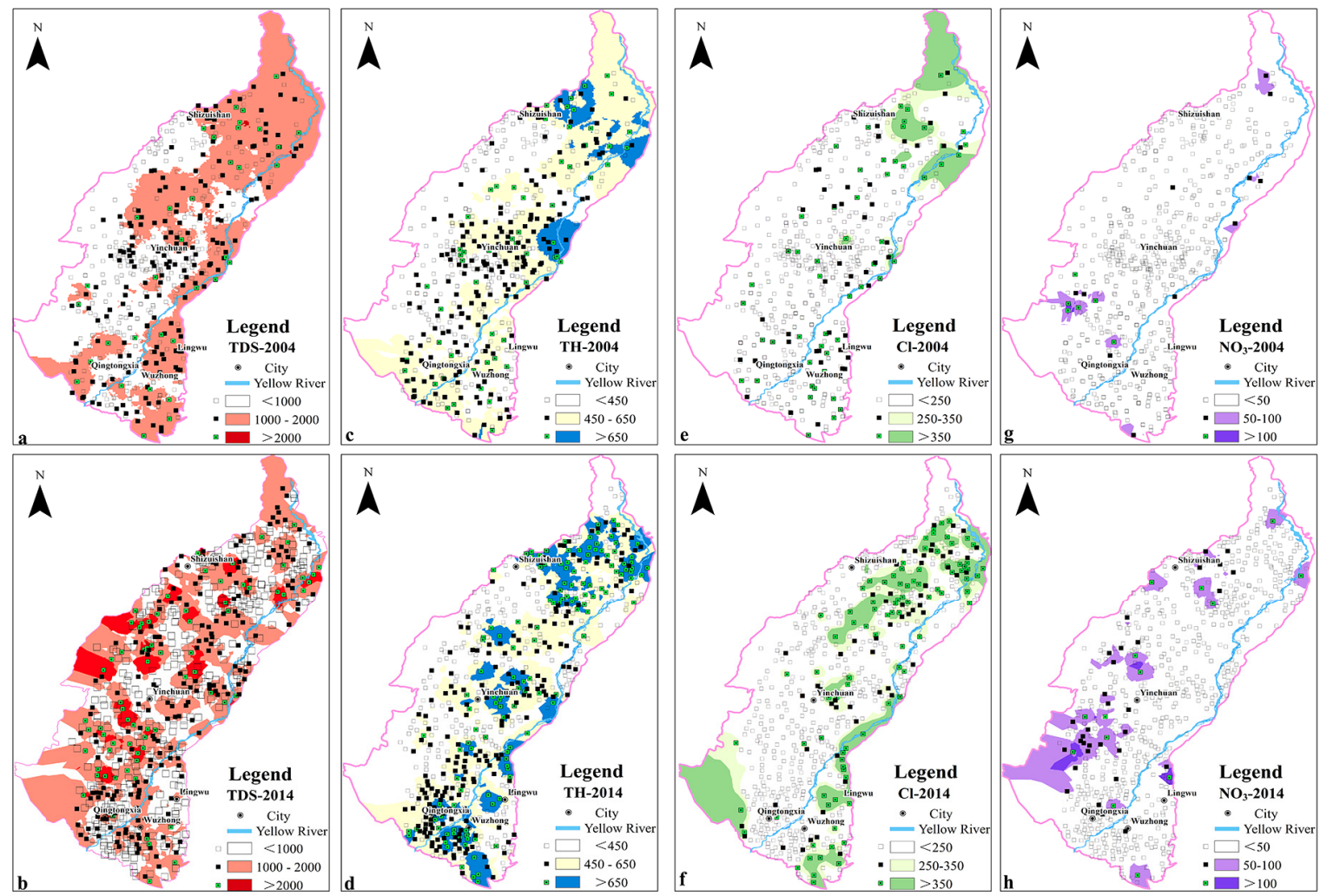

Figure 8. Spatial distribution of some typical pollutants: total dissolved solids (TDS) in (a) 2004 and (b) 2014, total hardness (TH) in (c) 2004 and (d) 2014, $\mathrm{Cl}^{-}$concentration in (e) 2004 and (f) 2014, and $\mathrm{NO}_{3}^{-}$ concentration in (g) 2004 and (h) 2014.

The increasing levels of both $\mathrm{TH}$ and $\mathrm{Cl}^{-}$in 2014 were correlated with rural residential areas, urbanization, and agriculture activity (Figure 9). Potential sources of groundwater hardening and chloride pollution are similar. As with $\mathrm{Cl}^{-}$, the majority of locations were suitable for drinking except for some northern and central areas (Figure 8e). In 2014, $\mathrm{Cl}^{-}$was slightly higher than in 2004 (Figure 8e,f). The higher levels were related to rural residential, urbanized, and irrigated regions (Figure 9) and could thus be attributed mainly to sewage infiltration and irrigation return flow. For example, over-pumping leads to lower hydraulic heads and can induce influxes of poorer quality water (such as untreated sewage and irrigation return flow) [53].

The concentration of $\mathrm{NO}_{3}^{-}$can be a good indicator for interactions between anthropogenic effects and natural processes $[50,54,55]$. In 2004, $\mathrm{NO}_{3}^{-}$concentrations were generally low $(0-2 \mathrm{mg} / \mathrm{L})$. Only some locations along the Yellow River in the northern parts of the region exceeded the permissible limit. The spatial distribution of $\mathrm{NO}_{3}$ contents showed a higher variation throughout the study area between 2004 and 2014 (Figure 8g,h). The increase in nitrate content was directly related to relatively dense rural settlements and extensive agricultural activity typical of the middle western, southwestern, and southern parts of the plain (Shizuishan, Lingwu, and Wuzhong). Urbanization was also a potential factor for the elevated nitrate concentrations in the southwest (near Yinchuan). This clearly shows the contribution of anthropogenic effects (such as agriculture and waste discharge), on groundwater quality with respect to the higher amounts of $\mathrm{NO}_{3}^{-}$released over the study period. 


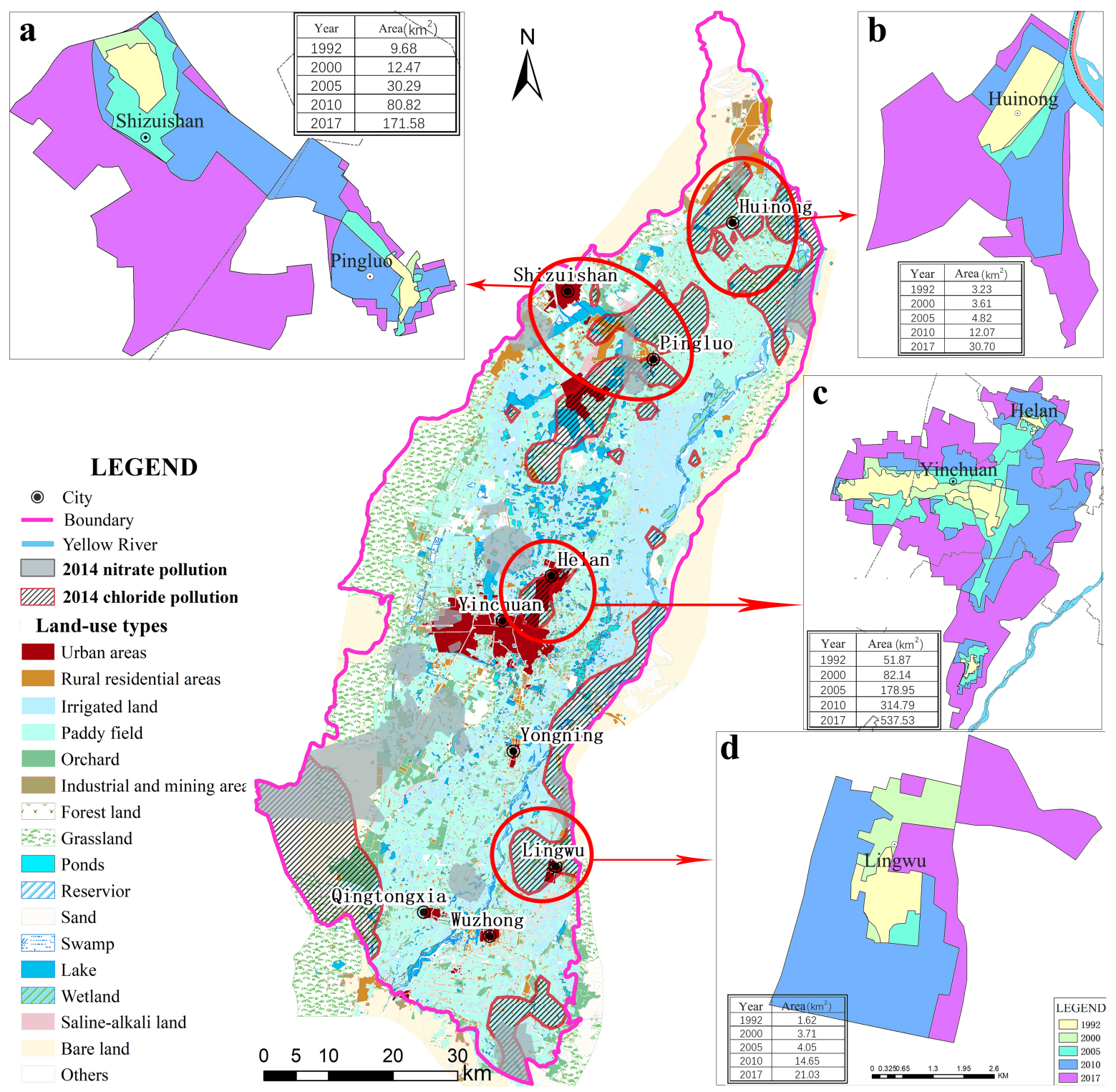

Figure 9. Map of land use types and the spatial distribution of nitrate and chloride pollution and urban expansion in 1992, 2000, 2005, 2010, and 2017. Spatial distribution of urban expansion of: (a) Shizuishan, (b)Huinong, (c) Yinchuan, and (d) Lingwu.

\subsection{Anthropogenic Effects on Pollutants}

Nitrate pollution in the study area may be caused by the leakage, leaching, and infiltration of untreated sewage or other solid waste in rural areas [47,56] (Figure 9). Rural residential areas often have poor sewage treatment and waste-disposal infrastructure. Nitrate enrichment during the infiltration of waste would be facilitated by soil microbial activity and the input of organic nitrogen.

Artificial fertilizers are another principle source of nitrates. The area's fertile alluvial plains (deposited by the Yellow River) favor extensive agriculture with cropping patterns that increase fertilizer use, such as wheat and corn which require high applications of N-based fertilizers [57-59]. Our field investigations confirmed that areas with higher nitrate pollution corresponded to the cultivation of these crops, such that excessive use of $\mathrm{N}$-fertilizers at the soil surface could result in nitrate leaching into groundwater after long-term irrigation.

The distribution of chloride pollution was similar to urban expansion in Shizuishan, Pingluo, Huinong, Yinchuan, and Lingwu (Figure 9). These trends presented urban sources of chloride. 
The concentration of salinity from landfills and septic and sewer systems increased chloride in groundwater. The $\mathrm{Cl}^{-}$concentration increase in groundwater may also be influenced by road salt. The low average total annual snowfall and the few average annual number of individual days of snowfall indicated road salt application make a small contribution to the chloride concentration increase.

Our results clearly show that groundwater salinization and overall quality in the study area were affected by climate, lithology, and human activity. Anthropogenic sources were the principal factor for nitrate and chloride contamination, such as in extensive irrigation, over-fertilization, untreated waste-water discharge, and the infiltration of municipal solid waste and livestock manure. Additionally, lower groundwater levels caused by over-pumping and sandy soils with high porosity accelerated the transport of contaminants into the groundwater.

Compared to 2004, clearly higher levels of $\mathrm{TH}, \mathrm{Cl}^{-}$, and $\mathrm{NO}_{3}^{-}$were found along the edge of the southeastern plain (north of Lingwu, Figure 9) in 2014, radiating outward over a decreasing gradient (Figure $8 \mathrm{~d}, \mathrm{f}, \mathrm{h}$ ). This pattern could be closely related to the Ningdong coal power and chemical industry base (NDEC), established in 2003 northeast of Lingwu, a few kilometers outside of the study area. Point source pollution from NDEC (such as industrial wastewater or local atmospheric deposition) enters the local groundwater and flows into the study area toward the Yellow River, creating the radial distribution seen here.

\section{Conclusions}

We combined multivariate statistics and hydrogeochemical methods to investigate natural and anthropogenic influences on groundwater quality in the Yinchuan Plain, China. Our results showed that concentrations of TDS, $\mathrm{TH}, \mathrm{Na}^{+}, \mathrm{Ca}^{2+}, \mathrm{Mg}^{2+}, \mathrm{Cl}^{-}, \mathrm{SO}_{4}^{2-}, \mathrm{HCO}_{3}^{-}$and $\mathrm{NO}_{3}^{-}$in the study area increased from 2004-2014, whereas the concentration of $\mathrm{K}^{+}$declined. The concentrations of TDS, TH, $\mathrm{Na}^{+}, \mathrm{Cl}^{-}$, $\mathrm{SO}_{4}^{2-}, \mathrm{NO}_{3}^{-}$, and $\mathrm{F}^{-}$were above the $\mathrm{WHO}$ groundwater quality limit. The groundwater chemistry of the study area was dominated by $\mathrm{Ca}-\mathrm{HCO}_{3}, \mathrm{Na}-\mathrm{Cl}$, and mixed $\mathrm{Ca} \cdot \mathrm{Mg}-\mathrm{Cl}$ water types, without obvious changes during the study period. The main hydrogeochemical processes controlling the groundwater salinity and quality were evaporation, ion exchange processes, and water-rock interaction. Saturation indices and ionic ratios showed that gypsum, halite, and fluorite were under-saturated in 2004 and 2014.

The hydrochemistry of the study area was also affected by anthropogenic activity including fertilizer use, sewage input, and irrigation infiltration. Correspondence analysis identified typical pollutants including TH, chloride, TDS, and nitrate, which together accounted for $84.37 \%$ and $81.23 \%$ of the total variance in 2004 and 2014, respectively. Possible factors influencing these pollutants include evaporation, dissolution of various minerals, irrigation return flow, raw sewage, and the use of gypsum or nitrate fertilizers. Geostatistical analysis showed that the spatial distribution of typical pollutants was influenced by fertilization, irrigation, rural waste discharge, urbanization, and industrial activity. Overall, the groundwater quality in the study area experienced a deteriorating trend during the study period. Our study provides a reliable and valuable way to assess hydrogeochemical characteristics and pollution sources of groundwater in semi-arid regions under anthropogenic influences, which could potentially be applied to other similar regions around the world.

Supplementary Materials: The following are available online at http://www.mdpi.com/2073-4441/11/11/2247/s1, Figure S1: Map of land use types in the study area.

Author Contributions: Conceptualization, L.W. and K.Y.; software, L.W. and X.M.; validation, F.H., K.Y. and Y.M.; formal analysis, L.W.; investigation, Y.L. and X.M.; data curation, L.W.; writing-original draft preparation, L.W.; writing—review and editing, Y.M.; project administration, Y.L.

Funding: This research was funded by the Hydrogeological and Environmental Geological Survey of Ningxia Yellow River Economic Belt (1212011220973), Groundwater Exploitation and Utilization \& Ecological Environmental Protection Survey of Ningxia Yellow River Ecological and Economic Belt, National Key R\&D Program of China (2018YFC0406404), and Program of the China Geological Survey (DD20189270).

Acknowledgments: Anonymous reviewers and the Editor are sincerely acknowledged for their useful comments. 
Conflicts of Interest: The authors declare no conflict of interest.

\section{References}

1. El Alfy, M.; Lashin, A.; Abdalla, F.; Al-Bassam, A. Assessing the hydrogeochemical processes affecting groundwater pollution in arid areas using an integration of geochemical equilibrium and multivariate statistical techniques. Environ. Pollut. 2017, 229, 760-770. [CrossRef] [PubMed]

2. Purushotham, D.; Prakash, M.R.; Rao, A.N. Groundwater depletion and quality deterioration due to environmental impacts in Maheshwaram watershed of R.R. district, AP (India). Environ. Earth Sci. 2011, 62, 1707-1721. [CrossRef]

3. Abu-alnaeem, M.F.; Yusoff, I.; Ng, T.F.; Alias, Y.; Raksmey, M. Assessment of groundwater salinity and quality in Gaza coastal aquifer, Gaza Strip, Palestine: An integrated statistical, geostatistical and hydrogeochemical approaches study. Sci. Total Environ. 2018, 615, 972-989. [CrossRef] [PubMed]

4. Ben Moussa, A.; Zouari, K.; Oueslati, N. Geochemical study of groundwater mineralization in the Grombalia shallow aquifer, north-eastern Tunisia: Implication of irrigation and industrial waste water accounting. Environ. Geol. 2009, 58, 555-566. [CrossRef]

5. Ogrinc, N.; Tamše, S.; Zavadlav, S.; Vrzel, J.; Jin, L.X. Evaluation of geochemical processes and nitrate pollution sources at the Ljubljansko polje aquifer (Slovenia): A stable isotope perspective. Sci. Total Environ. 2019, 646, 1588-1600. [CrossRef] [PubMed]

6. Yang, Q.C.; Wang, L.C.; Ma, H.Y.; Yu, K.; Martín, J.D. Hydrochemical characterization and pollution sources identification of groundwater in Salawusu aquifer system of Ordos Basin, China. Environ. Pollut. 2016, 216, 340-349. [CrossRef] [PubMed]

7. Dobaradaran, S.; Mahvi, A.H.; Nabizadeh, R.; Mesdaghinia, A.; Naddafi, K.; Yunesian, M.; Rastkari, N.; Nazmara, S. Hazardous organic compounds in groundwater near Tehran automobile industry. Bull. Environ. Contam. Toxicol. 2010, 85, 530-533. [CrossRef]

8. Rösner, U. Effects of historical mining activities on surface water and groundwater-An example from northwest Arizona. Environ. Geol. 1998, 33, 224-230. [CrossRef]

9. Chen, J.Y.; Taniguchi, M.; Liu, G.Q.; Miyaoka, K.; Onodera, S.I.; Tokunaga, T.; Fukushima, Y. Nitrate pollution of groundwater in the Yellow River delta, China. Hydrogeol. J. 2007, 15, 1605-1614. [CrossRef]

10. Liu, G.D.; Wu, W.L.; Zhang, J. Regional differentiation of non-point source pollution of agriculture-derived nitrate nitrogen in groundwater in northern China. Agric. Ecosyst. Environ. 2005, 107, 211-220. [CrossRef]

11. Chang, J.X.; Wang, Y.M.; Istanbulluoglu, E.; Bai, T.; Huang, Q.; Yang, D.W.; Huang, S.Z. Impact of climate change and human activities on runoff in the Weihe River Basin, China. Quat. Int. 2015, 380, 169-179. [CrossRef]

12. Fan, J.; Tian, F.; Yang, Y.H.; Han, S.M.; Qiu, G.Y. Quantifying the magnitude of the impact of climate change and human activity on runoff decline in Mian River Basin, China. Water Sci. Technol. 2010, 62, 783-791. [CrossRef] [PubMed]

13. Xu, K.H.; Milliman, J.D.; Xu, H. Temporal trend of precipitation and runoff in major Chinese Rivers since 1951. Glob. Planet. Chang. 2010, 73, 219-232. [CrossRef]

14. Qin, C.B.; Su, Z.; Bressers, H.T.A.; Jia, Y.W.; Wang, H. Assessing the economic impact of North China's water scarcity mitigation strategy: A multi-region, water-extended computable general equilibrium analysis. Water Int. 2013, 38, 701-723. [CrossRef]

15. Wang, J.X.; Li, Y.R.; Huang, J.K.; Yan, T.T.; Sun, T.H. Growing water scarcity, food security and government responses in China. Glob. Food Secur. 2017, 14, 9-17. [CrossRef]

16. Chen, J.; Huang, Q.W.; Lin, Y.L.; Fang, Y.; Qian, H.; Liu, R.P.; Ma, H.Y. Hydrogeochemical characteristics and quality assessment of groundwater in an irrigated region, Northwest China. Water 2019, 11, 96. [CrossRef]

17. Jing, X.Y.; Yang, H.B.; Wang, W.K.; Cao, Y.Q. Hydro-geochemical simulation for the evolution of groundwater quality in Yinchuan Plain, China. Hydrol. Sci. J. 2016, 61, 2284-2294. [CrossRef]

18. Zhou, Y.H.; Wei, A.H.; Li, J.F.; Yan, L.D.; Li, J. Groundwater Quality Evaluation and Health Risk Assessment in the Yinchuan Region, Northwest China. Expo. Health 2016, 8, 443-456. [CrossRef]

19. Zhang, X.D.; Qian, H.; Wu, H.; Chen, J.; Qiao, L. Multivariate Analysis of Confined Groundwater Hydrochemistry of a Long-Exploited Sedimentary Basin in Northwest China. J. Chem. 2016, 2016. [CrossRef] 
20. Wu, H.; Chen, J.; Qian, H.; Zhang, X.D. Chemical Characteristics and Quality Assessment of Groundwater of Exploited Aquifers in Beijiao Water Source of Yinchuan, China: A Case Study for Drinking, Irrigation, and Industrial Purposes. J. Chem. 2015. [CrossRef]

21. Qian, H.; Li, P.Y.; Howard, K.W.F.; Yang, C.; Zhang, X.D. Assessment of groundwater vulnerability in the Yinchuan Plain, Northwest China using OREADIC. Environ. Monit. Assess. 2012, 184, 3613-3628. [CrossRef] [PubMed]

22. Zhu, L.; Yang, M.N.; Chen, X.; Liu, J.T. Health Risk Assessment and Risk Control: Drinking Groundwater in Yinchuan Plain, China. Expo. Health 2017, 11, 59-72. [CrossRef]

23. Ministry of Geology and Mineral Resources of China. Geology and Mineral Industry Standard of the People's Republic of China: Quality Detection Standard for Groundwater (DZ/T0064-93); Ministry of Geology and Mineral Resources of China: Beijing, China, 1993. (In Chinese)

24. Piper, A.M. A graphical procedure in geochemical interpretation of water analysis. Trans. Am. Geophys. Union 1944, 25, 914-928. [CrossRef]

25. Shakoor, M.B.; Bibi, I.; Niazi, N.K.; Shahid, M.; Nawaz, M.F.; Farooqi, A.; Naidu, R.; Rahman, M.M.; Murtaza, G.; Lüttge, A. The evaluation of arsenic contamination potential, speciation and hydrogeochemical behaviour in aquifers of Punjab, Pakistan. Chemosphere 2018, 199, 737-746. [CrossRef]

26. Gibbs, R.J. Mechanisms controlling world water chemistry. Science 1970, 170, 1088-1090. [CrossRef]

27. Yang, Y.G.; Meng, Z.L.; Jiao, W.T. Hydrological and pollution processes in mining area of Fenhe River Basin in China. Environ. Pollut. 2018, 234, 743-750. [CrossRef]

28. Jalali, M. Hydrochemical identification of groundwater resources and their changes under the impacts of human activity in the Chah basin in western Iran. Environ. Monit. Assess. 2007, 130, 347-364. [CrossRef]

29. Narany, T.S.; Ramli, M.F.; Aris, A.Z.; Sulaiman, W.N.A.; Juahir, H.; Fakharian, K. Identification of the Hydrogeochemical Processes in Groundwater Using Classic Integrated Geochemical Methods and Geostatistical Techniques, in Amol-Babol Plain, Iran. Sci. World J. 2014, 2014. [CrossRef]

30. Srinivasamoorthy, K.; Gopinath, M.; Chidambaram, S.; Vasanthavigar, M.; Sarma, V.S. Hydrochemical characterization and quality appraisal of groundwater from Pungar sub basin, Tamilnadu, India. J. King Sand Univ.-Sci. 2014, 26, 37-52. [CrossRef]

31. Zang, H.F.; Zheng, X.Q.; Jia, Z.X.; Chen, J.F.; Qin, Z.D. The impact of hydrogeochemical processes on karst groundwater quality in arid and semiarid area: A case study in the Liulin spring area, north China. Arab. J. Geosci. 2015, 8, 6507-6519. [CrossRef]

32. Appelo, C.A.J.; Postma, D. Geochemistry, Groundwater and Pollution, 2nd ed.; CRC Press: London, UK, 2004.

33. Usunoff, E.J.; Guzmán-Guzmán, A. Multivariate Analysis in Hydrochemistry: An Example of the Use of Factor and Correspondence Analyses. Groundwater 1989, 27, 27-34. [CrossRef]

34. Narany, T.S.; Sefie, A.; Aris, A.Z. The long-term impacts of anthropogenic and natural processes on groundwater deterioration in a multilayered aquifer. Sci. Total Environ. 2018, 630, 931-942. [CrossRef] [PubMed]

35. Liang, C.P.; Chien, Y.C.; Chen, C.F.; Chen, J.S. Spatial analysis of human health risk due to arsenic exposure through drinking groundwater in Taiwan's Pingtung Plain. Int. J. Environ. Res. Public Health 2017, 14, 81. [CrossRef] [PubMed]

36. Liang, C.P.; Chien, Y.C.; Wang, S.W.; Chen, J.S. The combined use of groundwater quality drawdown index and land use to establish a multi-purpose groundwater utilization plan. Water Resour. Manag. 2019. accepted. [CrossRef]

37. World Health Organization (WHO). Guidelines for Drinking Water Quality; World Health Organization: Geneva, Switzerland, 2011; pp. 468-475.

38. Bureau of Quality and Technical Supervision of China. National Standard of the People's Republic of China: Quality Standard for Groundwater (GB/T 14848-2017); Bureau of Quality and Technical Supervision of China: Beijing, China, 2017. (In Chinese)

39. Ganyaglo, S.Y.; Banoeng-Yakubo, B.; Osae, S.; Dampare, S.B.; Fianko, J.R. Water quality assessment of groundwater in some rock types in parts of the eastern region of Ghana. Environ. Earth Sci. 2011, 62, 1055-1069. [CrossRef]

40. Rezaei, A.; Hassani, H. Hydrogeochemistry study and groundwater quality assessment in the north of Isfahan, Iran. Environ. Geochem. Health 2018, 40, 583-608. [CrossRef] 
41. Rajmohan, N.; Elango, L. Hydrogeochemistry and its relation to groundwater level fluctuation in the Palar and Cheyyar river basins, southern India. Hydrol. Process. 2006, 20, 2415-2427. [CrossRef]

42. Haritash, A.K. Hydrogeochemical characterization and suitability appraisal of groundwater around stone quarries in Mahendragarh, India. Environ. Earth Sci. 2018, 77, 1-14.

43. Rina, K.; Singh, C.K.; Datta, P.S.; Singh, N.; Mukherjee, S. Geochemical modelling, ionic ratio and GIS based mapping of groundwater salinity and assessment of governing processes in Northern Gujarat, India. Environ. Earth Sci. 2013, 69, 2377-2391. [CrossRef]

44. Subba Rao, N. Seasonal variation of groundwater quality in a part of Guntur District, Andhra Pradesh, India. Environ. Geol. 2006, 49, 413-429. [CrossRef]

45. Al-Amry, A.S. Hydrogeochemistry and Groundwater Quality Assessment in an Arid Region: A Case Study from Al Salameh Area, Shabwah, Yemen. In Proceedings of the 3rd International Conference on Water Resources and Arid Environments, The 1st Arab Water Forum, Riyadh, Saudi Arabia, 16-19 November 2008.

46. Kanagaraj, G.; Elango, L.; Sridhar, S.G.D.; Gowrisankar, G. Hydrogeochemical processes and influence of seawater intrusion in coastal aquifers south of Chennai, Tamil Nadu, India. Environ. Sci. Pollut. Res. 2018, 25, 8989-9011. [CrossRef] [PubMed]

47. Li, D.N.; Gao, X.B.; Wang, Y.X.; Luo, W.T. Diverse mechanisms drive fluoride enrichment in groundwater in two neighboring sites in northern China. Environ. Pollut. 2018, 237, 430-441. [CrossRef] [PubMed]

48. Schoeller, H. Qualitative Evaluation of Ground Water Resources. In Methods and Techniques of Groundwater Investigation and Development, Water Resource Series, 1st ed.; Schoeller, H., Ed.; UNESCO: Paris, France, 1967; pp. 44-52.

49. Jebreen, H.; Wohnlich, S.; Banning, A.; Wisotzky, F.; Niedermayr, A.; Ghanem, M. Recharge, geochemical processes and water quality in karst aquifers: Central West Bank, Palestine. Environ. Earth Sci. 2018, 77, 261. [CrossRef]

50. Nazzal, Y.; Ahmed, I.; Al-Arifi, N.S.N.; Ghrefat, H.; Zaidi, F.K.; El-Waheidi, M.M.; Batayneh, A.; Zumlot, T. A pragmatic approach to study the groundwater quality suitability for domestic and agricultural usage, Saq aquifer, northwest of Saudi Arabia. Environ. Monit. Assess. 2014, 186, 4655-4667. [CrossRef]

51. Vengosh, A.; Gill, J.; Davisson, M.L.; Hudson, G.B. A multi-isotope (B, Sr, O, H, and C) and age dating $\left({ }^{3} \mathrm{H}_{-}{ }^{3} \mathrm{He}\right.$ and $\left.{ }^{14} \mathrm{C}\right)$ study of groundwater from Salinas Valley, California: Hydrochemistry, dynamics, and contamination processes. Water Resour. Res. 2002, 38,1-17. [CrossRef]

52. Robinove, C.J.; Langford, R.H.; Brookhart, J.W. Saline-Water Resources of North Dakota; United States Government Printing Office: Washington, DC, USA, 1958.

53. Hudak, P.F. Sulfate and chloride concentrations in Texas aquifers. Environ. Int. 2000, 26, 55-61. [CrossRef]

54. Trojan, M.D.; Maloney, J.S.; Stockinger, J.M.; Eid, E.P.; Lahtinen, M.J. Effects of land use on ground water quality in the anoka sand plain aquifer of minnesota. Groundwater 2003, 41, 482-492. [CrossRef]

55. White, P.; Ruble, C.L.; Lane, M.E. The effect of changes in land use on nitrate concentration in water supply wells in southern Chester County, Pennsylvania. Environ. Monit. Assess. 2013, 185, 643-651. [CrossRef]

56. Ferchichi, H.; Ben Hamouda, M.F.; Farhat, B.; Ben Mammou, A. Assessment of groundwater salinity using GIS and multivariate statistics in a coastal Mediterranean aquifer. Int. J. Environ. Sci. Technol. 2018, 15, 2473-2492. [CrossRef]

57. Ahada, C.P.S.; Suthar, S. Groundwater nitrate contamination and associated human health risk assessment in southern districts of Punjab, India. Environ. Sci. Pollut. Res. 2018, 25, 25336-25347. [CrossRef]

58. Jokela, W.E. Nitrogen Fertilizer and Dairy Manure Effects on Corn Yield and Soil Nitrate. Soil Sci. Soc. Am. J. 1992, 56, 148-154. [CrossRef]

59. Khalifa, K.; Zidan, A. Effect of nitrate addition on efficient use of ammonium sulfate fertilizer on corn under saline conditions. II. Field experiment. Commun. Soil Sci. Plant Anal. 2001, 32, 2373-2393. [CrossRef]

(C) 2019 by the authors. Licensee MDPI, Basel, Switzerland. This article is an open access article distributed under the terms and conditions of the Creative Commons Attribution (CC BY) license (http://creativecommons.org/licenses/by/4.0/). 